\title{
Prevalence of Primary Dysmenorrhea among Secondary School Students and Its Treatment Modalities in Fayed City
}

Shaimaa M. Abdel-Sattar, ${ }^{1 *}$, Nadia M. Mansour ${ }^{1}$, Tayseer M. Mostafa ${ }^{1}$, Samy A. Abel-Azim ${ }^{1}$

${ }^{1}$ of Family Medicine department, Faculty of Medicine, Suez Canal University, Egypt

\begin{abstract}
:
Background: Primary dysmenorrhea is a common problem of adolescent girls. It has a high prevalence in Egypt so it is important to evaluate the prevalence of dysmenorrhea and the treatment modalities used to alleviate it. Objective: To evaluate the prevalence of primary dysmenorrhea and its treatment modalities. Methods: This cross-sectional study was conducted on 95 students at four secondary schools in Fayed city from October to November 2017. Data were collected using a predesigned self-administered questionnaire and pain severity was measured by NRS. Results: The prevalence of primary dysmenorrhea was $(62 \%)$ and most of them had moderate pain $(74.6 \%)$. There was a low rate of doctor consultation (11.9\%). Also, 67.8\% of students took Analgesics and 40.7\% used complementary (hot water bottles, abdominal massage and hot herbal fluids) to alleviate menstrual pain. Conclusion: The prevalence of dysmenorrhea was high among female students in Fayed city and most of them used over the counter (OTC), analgesics and complementary methods to alleviate pain. Dysmenorrhea is strongly associated with some bad habits. It is important to spread awareness about the causes and treatment of dysmenorrhea to avoid undue sufferings.
\end{abstract}

Keywords: Dysmenorrhea, Students, Treatment modalities.

Introduction: Dysmenorrhea is one of the most common gynecological problems in menstruating girls. It is characterized by lower abdominal pain that can range widely in severity and other associated symptoms. Dysmenorrhea has a significant medical and psychosocial implications on menstruating girls. ${ }^{(1)}$ dysmenorrhea manifests as painful menstrual flow. ${ }^{(2)}$ It occurs in two forms: primary and secondary dysmenorrhea (SD). Primary dysmenorrhea (PD) is painful menstruation occurring without any gynecological disease.

The secondary form is subsequent to a gynecological pathology such as endometriosis and ovarian cysts. (1) The reported prevalence of dysmenorrhea has ranged from $15.8 \%$ to $89.5 \%$, with higher rates reported in adolescent populations. ${ }^{(3)}$ In a study conducted in Egypt among school students which showed that the overall prevalence of dysmenorrhea was $74.6 \%$; it was significantly more frequent among students from a rural residence and in those from low social classes. ${ }^{(4)}$

Another study conducted in Egypt showed that the prevalence of dysmenorrhea was detected in $94.4 \%$ of the study population. ${ }^{(5)}$ Painful menstruation has an impact on the everyday tasks, such as going to school, playing and diet restriction which could affect their quality of life. ${ }^{(6)}$ Treatment of PD is to 
reduce the cramping pelvic pain and associated symptoms. To date, pharmacotherapy has been the most effective treatment for relieving dysmenorrhea. ${ }^{(7)}$ Nonsteroidal anti-inflammatory drugs (NSAIDs) and combination oral contraceptives (OCs) are the most commonly used therapeutic modalities for the management of primary dysmenorrhea. An integrative medicine is one of the most treatment modalities worldwide.

Many young girls in our country may lack information on dysmenorrhea, causing unhealthy behavior during their menstrual Period. So this study was designed as a survey questions to assess the prevalence, pattern of dysmenorrhea and different treatment methods whether pharmacological or alternatives aim to improve the girl's health practice toward menstruation.

Methods: The study was a cross sectional study. It was conducted on four secondary schools in Fayed city during period of October- November 2017. It was carried out on 96 female students (calculated sample size) and they were selected from each school by stratified simple random method. Inclusion criteria of the study population included female students aged from 15-20 year with a history of menstruation and those with pain started a few hours before the onset of menstruation or with its onset with lower abdominal pain, lower back pain and anterior thigh pain lasting for 9-72 hours. Exclusion criteria included the following; history of any chronic pelvic diseases (like ovarian cyst, fibroid or endometriosis) or who have a major pelvic surgery, married and taking oral contraceptive pills.

A self-administered questionnaire was used to inquire about socio-demographic and clinical data such as weight, height, age, residence and educational level of parents, menstrual characteristics, and from whom the participants asked for information and help regarding menstruation, symptoms of primary dysmenorrhea, a numeric pain rating scale evaluation was used for participants who said that they had painful menstruation. In the concerned scale the participants rated the severity of their pain between 1 and 10 .

Respondents were asked to select the single number that best represents their pain intensity. According to Numerical Rating Scale (NRS), three ranges of pain: 1-3 for mild pain, 4-7 for moderate pain, and 8-10 for severe pain (8) and data on treatment modalities. The questionnaire provided from Polat et al study. ${ }^{(9)}$ It was translated from English to Arabic by bilingual expert, the questionnaire was tested for reliability by pilot study not enrolled in this study result (10 students) and the Cronbach's alpha was 0.72, 
while content validity was assessed by supervisors.

Ethical considerations: The research protocol was approved by Ethical Committee of Faculty of Medicine- Suez Canal University with informed consent from every participant in the study, assuring the confidentiality of information and test results and the right of each participant to withdraw of the study at any time.

Statistical analysis: Data were analyzed by (SPSS) program version 18. The statistical tests were used (qualitative data were expressed as numbers and percentage). The results were presented in tables and figures.

Results: The present study was conducted on 95 participants with the mean age of participants was $17.23( \pm 1.34)$ years and ranged from 15 - 19 years with the mean weight of $56.28( \pm 7.06)$ and the mean height of $158.63( \pm 5.55)$. The majority of participants were from rural areas $(82.1 \%)$. According to parents' education, about $17.9 \%$ of mothers were illiterate and $20 \%$ were highly educated. The study showed that the Prevalence of dysmenorrhea among students is $62 \%$ and only $38 \%$ have no dysmenorrhea.

The study demonstrate that patterns of menstrual pain among students with dysmenorrhea showed that most of students $(96.6 \%)$ start to suffer from pain on $1^{\text {st }}$ day of menstruation usually last for one day (69.5\%) and according to NRS, the majority of students have Moderate pain (74.6\%) with only $11.9 \%$ seek doctor consultation.

More than two-thirds (67.8\%) and 40.7\% of study group use medications and complementary methods respectively to alleviate pain (Table 1). The frequency distribution of pain relief methods used by female students to alleviate symptoms of dysmenorrhea shows that most of students (45.8\%) take analgesic tablets and $8.5 \%$ take analgesic injections with $40 \%$ need additional complementary pain killers in form of hot drinks, hot water bottles applied on lower abdomen and abdominal massage (Table 2).The study shows that $73.33 \%$ of students used fenugreek drink, 53.3\% used Anise drink, $40 \%$ used menthol, $13.3 \%$ used cinnamon and $13.3 \%$ used ginger drink to relieve menstrual pain.

Discussion: The current study confirms that primary dysmenorrhea was found to be $62 \%$. This result was in agreement with the result of Aljefout (2015) ${ }^{10}$, Nooh (2015) $)^{11}$ and Suvitie et al. (2016) ${ }^{12}$ who stated that the prevalence of PD was $55.8 \%, 65.4 \%, 68 \%$ respectively. Also this study result was in partial agreement with Abd El-mawgod et al. (2016) ${ }^{13}$ and El Gilany et al. $(2005)^{4}$ who stated that the prevalence of PD was $74.4 \%$ and $74.6 \%$ 
respectively. The result of the current study was different from the obtained result from a study conducted by Mohamed et al. $(2011)^{5}$ who stated that the prevalence of dysmenorrhea was $94.4 \%$. The higher prevalence in Mohamed's study may be due to different study sitting in El-Minia governorate and difference in pain perception and pain threshold among different populations as reported by (Baknikarim et al., 2000). ${ }^{14}$

Parker et al. $(2010)^{15}$ had higher prevalence of PD as the prevalence was $93 \%$ among Australian teenagers. The difference between Parker result and this result could be due to larger number of adolescents about 1051 were recruited in his study and different population. This study differs from Ohde et al. $(2008)^{3}$ and Laszlo et al. $(2008)^{16}$ who stated that the prevalence of dysmenorrhea was $16 \%$ and $15.5 \%$ respectively.

The difference between Ohde result and this study result may be due to changes in the selected group of subjects as it was conducted in Japanese females aged from 17-51 years and also this study differs from Laszlo study due to absence of a universally accepted method and criteria for defining dysmenorrhea as he defined dysmenorrhea as menstrual pain that cause limitation of activity. This study showed that $96.6 \%$ of students said that their pain started on the first menstrual day this was in concordance with other study conducted in Turkey, which showed that $72.9 \%$ of the students said their pain started on the first menstrual day (Polat et al., 2009) ${ }^{9}$. Also the study of Seven et al. $(2014)^{17}$ showed that menstrual pain was frequently initiated on the first day of menstruation in $77.8 \%$ of students which is consistent with this study.

Concerning the duration of menstrual pain, This study showed that $69.5 \%$ of students reported that their pain lasted for one day duration and $30.5 \%$ of them said that their pain lasted for two to three day duration and this in agreement with El-Gilany et al. (2005) who stated that duration of pain was less than 24 hours in $64.9 \%$ of participants and about $35 \%$ stated that their pain lasted for two to three day durations and this is matched with the characteristics of PD pain.

Concerning the severity of pain, the current study showed that only $5.1 \%$ reported that their pain was severe according to numerical pain rating scale which is not in agreement with Suvitie et al. (2016) ${ }^{11}$ who stated that severe dysmenorrhea reported by $33 \%$ of adolescent girls in Southwest Finland by using numerical pain rating scale. Also this result is inconsistent with George et al. $(2014)^{8}$ who stated that $17.6 \%$ of adolescent 
girls in India reported dysmenorrhea according to NRS. This difference in pain severity may be related to ethnicity difference in pain perception and variability in pain threshold which is reported by Baknikarim et al. $(2000)^{13}$.

Also this results was different from reported results by al-Kindi and Al- Bulushi $(2011)^{18}$ who stated that $32 \%$ of Omani high school students had severe dysmenorrhea, which is more than the result of the current study by using multidimensional scoring system and this difference may be related to difference in system for grading PD severity. This study showed that only $11.9 \%$ seek medical consultation which is consistent with Mohamed (2012) ${ }^{19}$ who stated that only 9\% seek medical consultation. This low rate of medical consultation may be due to females were concerning dysmenorrhea as normal phenomena that doesn't need medical evaluation.

Concerning treatment modalities used by adolescent students to alleviate menstrual pain the current study revealed that $67.8 \%$ took analgesic medications which is on the contrary of Wong and Khoo $(2010)^{20}$, George et al. (2014) ${ }^{8}$ and Al-Kindi and Al-Bulushi $(2011)^{18}$ who stated that only $14.8 \%, 10.2 \%$ and $21 \%$ took medical treatments respectively and this may be related to the fact that some girls perceive dysmenorrhea as normal and may be due to cultural belief among Asian, Indian and Omani girls respectively. The current study result was in agreement with Mohamed (2012) ${ }^{19}$ and Arafa et al. (2017) ${ }^{21}$ who stated that $56 \%$ and $61.5 \%$ of participants took medical treatment respectively to relief dysmenorrhea. This may be explained by wide variation in the attitude of medicine taking or in the tolerance to pain between people or regions.

The current study showed that $40.7 \%$ of adolescents took complementary methods in the form of $8.5 \%$ were using hot water bottles, $25.4 \%$ were using hot drinks and $6.8 \%$ were using abdominal massage which is consistent with Mohamed et al. $(2011)^{5}$ who stated that $44 \%$ of female adolescents were using complementary methods in the form of hot water bottles in a percent $14.9 \%$ and herbal fluids in a percent $20.1 \%$. Also this study result is consistent with George et al. $(2014)^{8}$ who found that $10.2 \%$ of Indian girls apply abdominal massage, $12.3 \%$ apply hot water bottles on abdomen.

This study result was inconsistent with Seven et al. $(2014)^{17}$ who stated that $63.2 \%$ were using heating pads and $34.3 \%$ were using abdominal massage methods to relieve menstrual pain. This high percentage may be related to cultural difference between 
Egyptian and Turkish students. Also this study result was in concordance with Arafa et al. $(2017)^{21}$ who stated that $61.8 \%$ of females took herbal fluids to alleviate their menstrual pain and this high percentage of herbal fluids that females were using to alleviate their pain in Arafa study may be due to cultural difference between adolescents in Upper Egypt and the current study participants. The current study showed that hot drinks used by adolescent females to alleviate menstrual pain were fenugreek, anise, menthol, cinnamon and ginger respectively and this is in agreement with Mohamed et al. $(2011)^{5}$ who revealed that females use fenugreek; anise and cinnamon to alleviate menstrual pain and such agreement could be due to cultural belief.

Study limitations: The results of this could not be generalized as the sample was not representative to students from all secondary schools.

Conclusion: The current study concluded that PD is highly prevalent among females that deserve more attention and there is low rate of doctor consultation regarding dysmenorrhea. Also females tend to use over the counter analgesics and complementary methods as hot fluids, abdominal massage and application of hot bottles on abdomen to alleviate menstrual pain.
Acknowledgment: The authors would like to thank family medicine department affiliated to Faculty of Medicine, Suez Canal University, and all female students who accepted to participate in this study.

Conflict of interest: There is no conflict of interest to be declared

\section{References:}

1. Harel Z. Dysmenorrhea in adolescents. Ann N Y Acad Sci. Wiley Online Library; 2008;1135(1):185-95.

2. Lefebvre G, Pinsonneault O, Antao V, Black A, Burnett M, Feldman K, et al. Primary dysmenorrhea consensus guideline. J Obs Gynaecol Can. 2005;27(12):1117-46.

3. Ohde S, Tokuda Y, Takahashi O, Yanai H, Hinohara S, Fukui T. Dysmenorrhea among Japanese women. Int J Gynecol Obstet.2008;100(1):13-7.

4. El Gilany AH, Badawi K, El Fedawy S. Epidemiology of dysmenorrhoea among adolescent students in Mansoura, Egypt.East Mediterr Health J. 2005;11(12):155-163.

5. El-Hameed NAA, Mohamed MS, Ahmed NH, Ahmed ER. Assessment of dysmenorrhea and menstrual hygiene practices among adolescent girls in some nursing schools at EL-Minia Governorate, Egypt. J Am Sci. 2011;7(216):223. 
6. Ahuja A., Sharma M. and Singh A. Impact of Dysmenorrhea on Quality of Life of Adolescent Girls of Chandigarh. JOCB.2016; 4: 295.

7. Akin $\mathrm{MD}$, Weingand $\mathrm{KW}$, Hengehold DA, Goodale MB, Hinkle RT, Smith RP. Continuous low-level topical heat in the treatment of dysmenorrhea. Obstet Gynecol. 2001;97(3):343-9.

8. George N, Priyadarshini S. and Shetty S. Dysmenorrhoea among adolescent girlscharacteristics and symptoms experienced during menstruation. Nitte University J,2014; 4(3):45-52.

9. Polat A., Celik H., Gurates B., Kaya D. Kavak E. et al. Prevalence of primary dysmenorrhea in young adult female university students. Arch Gynecol Obstet. 2009;279 (4):527-32.

10. Al-Jefout M., Hijazeen J., Luskomb G., Abu-Fraijeh S., Ola A., Oday A. et al. Dysmenorrhea: Prevalence \& Impact on Quality of Life among Young Adult Jordanian Females. J Pediatr Adolesc Gynecol.2015;28 (3):173-85.

11. Nooh A. Menstrual disorders among Zagazig University Students, Zagazig, Egypt. Middle East Fertility Society J. 2015; 20(3): 198-203.

12. Suvitie P., Hallamaa M., Matomäki J., Mäkinen J. Perheentupa A. Prevalence of pain symptoms suggestive of endometriosis among finnish adolescent girls (TEENMAPS study). J Pediatr Adolesc Gynecol. 2016 ;29(2):97-103.

13. Abd El-Mawgod M., Alshaibany A. and Al-Anazi, A. Epidemiology of dysmenorrhea among secondary-school students in Northern Saudi Arabia. J Egypt Public Health Assoc. 2016; 91(3):115-119.

14. Banikarim C., Chacko M. and Kelder S. prevalence and impact of dysmenorrheal on Hispanic female adolescents. ,Archives of pediatrics \& adolescent medicine journal.2000;154(12):1226-1229.

15. Parker M., Sneddon A. and Arbon P. The menstrual disorder of teenagers (MDOT) study: determining typical menstrual patterns and menstrual disturbance in a large population based study of Australian teenagers', BJOG: An International Journal of Obstetrics \& Gynaecology.2010 Jan;117(2):185-92.

16. Laszlo K., Gyorffy Z., Adam S., C soboth C. Kopp M. Work related stress factors and menstrual pain: a nation-wide representative survey. J Psychosom Obstet Gynaecol.2008; 29(2):133-138.

17. Seven M, Güvenç G, Akyüz A, Eski F. Evaluating dysmenorrhea in a sample of 
Turkish nursing students. Pain Manag Nurs.2014;15(3): 664-71.

18. Al-Kindi R. and Al-Bulushi A. Prevalence and impact of dysmenorrhoea among Omani high school students. Sultan Qaboos University Medical Journal. 2011; 11(4): 485-491.

19. Mohamed E. Epidemiology of dysmenorrhea among adolescent students in Assiut city, Egypt. Life Science Journal.2012; 9(1): 348-353.
20. Wong L. and Khoo E. Dysmenorrhea in a multiethnic population of adolescent Asian girls International. Journal of obstetric and gynaecology. 2010;108(2):139-142.

21. Arafa A., Khamis Y., Hassan H., Saber N., Abbas M. Epidemiology of dysmenorrhea among workers in Upper Egypt; A cross sectional study. Middle East Fertility Society Journal. 2017;23 (1) 0-3. 
Table (1): Patterns of menstrual pain among students with dysmenorrhea

\begin{tabular}{|c|c|c|c|}
\hline \multicolumn{2}{|r|}{ Parameter } & \multicolumn{2}{|c|}{ Frequency $(\mathrm{N}=59)$} \\
\hline & & No. & $\%$ \\
\hline \multirow[t]{3}{*}{ Onset of pain } & - Few hours before menses & 1 & $1.7 \%$ \\
\hline & - $\quad 1^{\text {st }}$ day & 57 & $96.6 \%$ \\
\hline & - $2^{\text {nd }}$ day & 1 & $1.7 \%$ \\
\hline \multirow{2}{*}{$\begin{array}{l}\text { Duration of } \\
\text { pain }\end{array}$} & - One day & 41 & $69.5 \%$ \\
\hline & - Two to three day & 18 & $30.5 \%$ \\
\hline \multirow[t]{3}{*}{ Severity of pain } & - $\quad$ Mild (1-3) & 12 & $20.3 \%$ \\
\hline & - $\quad$ Moderate (4-7) & 44 & $74.6 \%$ \\
\hline & - $\quad$ Severe $(\geq 8)$ & 3 & $5.1 \%$ \\
\hline \multicolumn{2}{|c|}{ Need for medical consultation } & 7 & $11.9 \%$ \\
\hline \multicolumn{2}{|c|}{ Use of conventional medications } & 40 & $67.8 \%$ \\
\hline \multicolumn{2}{|c|}{ Use of complementary methods } & 24 & $40.7 \%$ \\
\hline
\end{tabular}

Table (2): Frequency distribution of pain relief methods used by students

\begin{tabular}{|c|c|c|c|}
\hline \multirow{2}{*}{\multicolumn{2}{|c|}{ Methods of pain relief }} & \multicolumn{2}{|c|}{ Frequency $(\mathrm{N}=59)$} \\
\hline & & \multirow{2}{*}{$\begin{array}{l}\text { No } \\
27 \\
\end{array}$} & \multirow{2}{*}{$\begin{array}{c}\% \\
45.8 \% \\
\end{array}$} \\
\hline \multirow{3}{*}{ Medications } & - Analgesic tablets & & \\
\hline & - Analgesic injections & 6 & $10.1 \%$ \\
\hline & - Both tablets and injections & 7 & $11.9 \%$ \\
\hline \multirow{3}{*}{ Complementary } & - Hot water bottle & 5 & $8.5 \%$ \\
\hline & - Abdominal massage & 4 & $6.8 \%$ \\
\hline & - Hot drinks & 15 & $25.4 \%$ \\
\hline
\end{tabular}




\section{Hot fluids used during dysmenorrhea}

Percentage

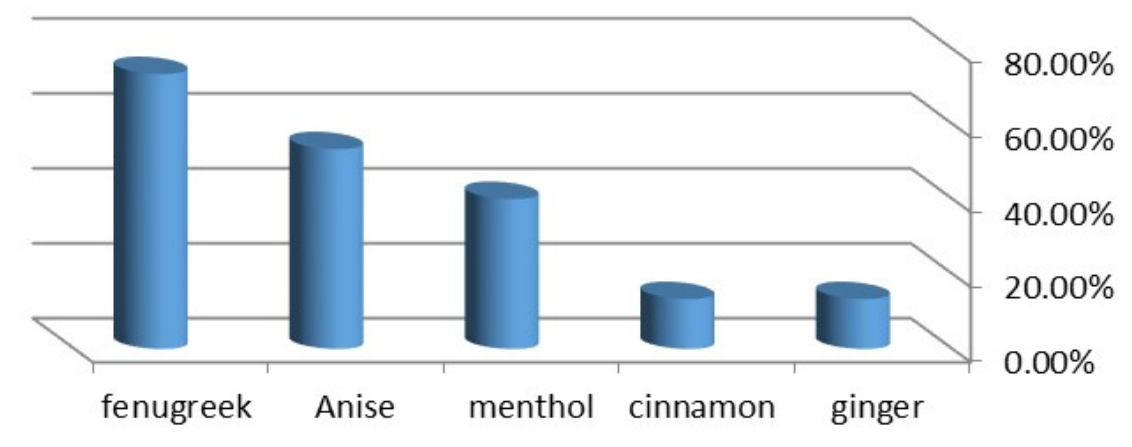

Figure (1): Types of hot fluids that used by students to alleviate menstrual pain. 


\section{الملخص العربي}

\section{انتشار عسر الطمث الأولي بين طالبات المدارس الثانوية والطرق المختلفة لعلاجه في مدينة فايا}

شيماء مجدي عبد الستار ـ نادية مبروك منصور - تيسير منولي مصطفى ـ سامى عبد الرازق عبد العظيم

الخلفيه: يعد عسر الطمث أحد المشاكل الصحية الأكثر شيو عا في الاناث خلال فترة الحيض.ويحدث ذلك في شكلين: عسر الطمث الاولي والثانوي. عسر الطمث الاولي هو الذي يحدث دون وجود أية أمر اض نسائية، وغالبا ما تبدأ من ستة إلى اثني عشر شهرا بعد بداية الحيض، وربما يستمر حتي انقطاع الطمث. على الرغم من أن عسر الطمث الثانوب يمكن أن يحدث في أي وقت في حياة المر أة بين فترة بداية الحيض وحتى انقطاع الطمث، ولكنه غالبا ما يحدث في سن الخامسة و العثرين ويكون نتيجة لبعض الأمر اض النسائية مثل التهاب بطانة الرحم وتكيس المبيض. وعادة ما يبدأ عسر الطمث الأولي مع بداية الحيض ويستمر لمدة تتراوح من ثمان ساعات حتي ثلاثة ايام. بالرغم من عدم وجود ما يكفي من المعلومات عن مسببات عسر الطمث الاولي الا ان المزيج من العوامل مثل زيادة افراز البروستاجلاندين وتحفيز الياف الالم من النوع سي تلعب دورا مهما في عسر الطمث الاولي. عسر الطمث له آثار ضارة مختلفة على الأفراد والمجتمع. على سبيل المثال، التغيب عن العمل والمدرسة ، و التعارض مع الأنشطة اليومية والحد في التنشئة الاجتماعية مما يسبب القلق ويؤثر علي أداء الانشطة اليومية والاكاديمية. الاهداف: تقييم مدى انتشارعسر الطمث الأولي وطرق العلاج المختلفة بين طلاب المدارس الثانوية في مدينة فايد بمحافظة الإسماعيلية.طرق الاراسة والبحث: أجريت در اسة مقطعية مستعرضة علي 95 طالبة تتراوح أعمار هم بين 15 و 20 سنة في أربع مدارس ثنانوية بمدينة فايد محافظة الإسماعيلية. الاستتتاجات: نستخلص من هذة الدراسة أن معدل انتشار عسر الطمث الأولي(62\%) ومن بينهم (20 (20 لا\%) من الطلاب الذين يعانون من عسر الطمث أفادوا بأن آلامهم خفيفة، (6و74\%) من المر اهقين أفادوا بأن ألمهم معتدل و أفادت فقط (5و 1\%) أن كان آلامهم شديدة وفقا لمقياس تقييم الألم العددي.وفيما يتعلق بنمط آلام الطمث، أظهرت هذه الدراسة أن (696\%) من الطلاب قالوا إن آلامهم بدأت في اليوم الأول من الحيض، و(7و1\%) قالوا أن آلامهم بدأت في اليوم الثاني من الحيض، و(7و 1\%) قبل ساعات من الحيض. فيما يتعلق بمدة ألم الدورة الثهرية، أظهرت هذه الدراسة أن (5و69\%) من الطلاب أفادوا بأن آلامهم استمرت لمدة يوم واحد و (5و30٪) منهم قالوا إن الألم يستمر لمدة يومين إلى ثلاثة أيام.وأظهرت الدراسة أن (87\%) من الطلاب يتناولون أدوية مسكنة على الرغم من أن (1و5\%) فقط يعانون من عسر الطمث الثنديد و (7و40\%) يستخدمون طرقا تكميلية لتخفيف آلامهم الثهرية على شكل مشروبات ساخنة بنسبة (4و 25\%) وزجاجات الماء الساخن (5و8\%) و (8و6\%) استعملت تدليك البطن.وأظهرت الدراسة الحالية أن الحلبة واليانسون و النعناع و الزنجبيل والقرفة كانت تستخدم من قبل الإناث للتخفيف من آلام الطمث. التوصيات: يوصي بعمل جلسات تثقيف صحي من قبل الاطباء و مسئولي الصحة المدرسية للطالبات فيما يتعلق بعسر الطمث الاولي و علاقته ببعض العلاقات الخاطئة و الطرق المختلفة لعلاجه وتتظيم حلقات در اسية للتثقيف الصحي للطلبة المراهقين بشأن عسر الطمث وتشجيع الإناث اللاتي يعانين من عسر الطمث للتشاور مع الطبيب. 